\title{
Evaluation of diet, anthropometry and immunocompetence of young male athletes
}

\author{
D. Lacerda ${ }^{1}$, V. Cotta-de-Almeida ${ }^{2}$, A. Montero ${ }^{3}$, W. Savino ${ }^{1}$ and A. Marcos ${ }^{4}$ \\ ${ }^{1}$ Laboratory on Thymus Research, Dept of Immunology and ${ }^{2}$ Dept of Ultrastructure and Cell Biology, Institute Oswaldo \\ Cruz-Fiocruz, Rio de Janeiro, Brazil, ${ }^{3}$ Dpto Nutrición, Bromatología y Tecnología de los Alimentos, Facultad de Farmacia, \\ Universidad San Pablo-CEU, Madrid, Spain and ${ }^{4}$ Grupo inmunonutrición, Dpto Metabolismo y Nutrición, Instituto Frío, \\ Consejo Superior de Investigaciones Científicas, Madrid, Spain
}

Currently, it is well accepted that nutrition is an important factor for the development of the immune response. Epidemiological and clinical results suggest that any nutritional deficiency alters immunocompetence and increases the susceptibility to infections ${ }^{(1,2)}$. thus, the purpose of the present study was to compare the nutritional status of ten young male elite track and field athletes (20-48 $\mathrm{h}$ training/week) aged 13-18 years at a baseline state ( $48 \mathrm{~h}$ relaxation after training) with a control group consisting of ten volunteer students, matched by age and socio-economic status, who were doing $<8 \mathrm{~h}$ physical exercise/week. Nutritional status was assessed by dietary intake for $3 \mathrm{~d}$, anthropometry (BMI and triceps skinfold thickness) and immunocompetence (total counts of leucocytes, lymphocytes and lymphocyte subsets $(\mathrm{CD} 3, \mathrm{CD} 4, \mathrm{CD} 8, \mathrm{CD} 19$ and CD16+56)).

The energy intake was similar for athletes and controls ( $8327 v .8235 \mathrm{~kJ} / \mathrm{d}$ respectively), and lower than that recommended by the Food and Nutrition Board, Institute of Medicine ${ }^{(3)}$, the American Dietetic Association ${ }^{(4)}$ and the American Academy of Pediatrics ${ }^{(5)}$. BMI and triceps skinfold thickness were significantly lower for the athletes than for the controls. Total leucocyte and total lymphocyte counts were similar for both groups. However, a decrease in CD3, CD8, CD19 and CD16+56 lymphocyte subset counts was found for athletes in comparison with controls.

\begin{tabular}{|c|c|c|c|c|}
\hline & \multicolumn{2}{|c|}{ Controls $(n$ 10) } & \multicolumn{2}{|c|}{ Athletes $(n$ 10) } \\
\hline & Mean & SD & Mean & SD \\
\hline Age (years) & 16.3 & 1.38 & 17.1 & 0.80 \\
\hline Energy intake $(\mathrm{kJ})$ & 8235 & 672 & 8327 & 584 \\
\hline \multicolumn{5}{|l|}{ Anthropometric variables } \\
\hline Weight $(\mathrm{kg})$ & 68.7 & 6.63 & 63.7 & 7.63 \\
\hline Height $(\mathrm{m})$ & 1.75 & 0.68 & 1.76 & 0.77 \\
\hline BMI $\left(\mathrm{kg} / \mathrm{m}^{2}\right)$ & 22.5 & 1.18 & $20.7^{*}$ & 2.00 \\
\hline Triceps skinfold thickness (mm) & 11.9 & 2.78 & $5.67 *$ & 1.1 \\
\hline \multicolumn{5}{|l|}{ Immunological variables } \\
\hline Total leucocytes $\left(\right.$ cells $/ \mathrm{mm}^{3}$ ) & 6287 & 1533 & 5786 & 1026 \\
\hline Total lymphocytes $\left(\right.$ cells $/ \mathrm{mm}^{3}$ ) & 3413 & 1003 & 3527 & 918 \\
\hline \multicolumn{5}{|l|}{ Lymphocyte subsets (cells $/ \mathrm{mm}^{3}$ ): } \\
\hline CD3 & 1380 & 418 & $919^{*}$ & 380 \\
\hline $\mathrm{CD} 8$ & 659 & 224 & $432 *$ & 151 \\
\hline CD19 & 248 & 54 & $179 *$ & 60 \\
\hline CD16 + 56 (NK cells) & 257 & 73 & $185^{*}$ & 59 \\
\hline
\end{tabular}

$\mathrm{NK}$, natural killer. Mean values were significantly different from those of the controls (Student's $t$ test): $* P<0.05$.

These results suggest that the young athletes assessed in the current study could show subclinical malnutrition, with a leaner body and an impaired immunocompetence compared with the control group, although the dietary intake was similar for both groups but below recommendations. A higher-energy diet should be recommended for these high-performance athletes in order to avoid further risk of malnutrition and to avoid more serious complications, such as infections.

1. Gleeson M, Nieman DC \& Pedersen BK (2004) J Sport Sci 22, 115-125.

2. Moreira A, Kekkonen RA, Delgado L, Fonseca J, Korpela R \& Haahtela T (2007) Eur J Clin Nutr 61, 443-460.

3. Food and Nutrition Board, Institute of Medicine (2002) Dietary Reference Intakes for Energy, Carbohydrate, Fiber, Fat, Fatty Acids, Cholesterol, Protein and Amino Acids (Macronutrients). Washington, DC: National Academy Press.

4. American Dietetic Association (2000) J Am Diet Assoc 100, 1543-1556.

5. American Academy of Pediatrics (2006) Pediatrics 11, 544-559. 